\title{
UPAYA PEMBERDAYAAN IBU RUMAH TANGGA DI DESA KALIREJO LAWANG DENGAN TUJUAN MEMOTIVASI KEWIRAUSAHAAN MANDIRI
}

(Pelatihan pembuatan penganan cokelat dengan varian inovasi isi,rasa dan pengemasan)

\author{
Riski Febria Nurita
}

Fakultas Hukum Universitas Merdeka Malang

\begin{abstract}
Abstrak
Kegiatan ini dilaksanakan dengan latar belakang pemberdayaan dan ingin membantu meningkatkan produktivitas masyarakat di desa Klairejo,Kecamatan Lawang,Kabupaten Malang khususnya ibu rumah tangga dengan latar belakan keluarga Pra Sejahtera . Kegiatan ini dilaksanakan dengan cara memberi pelatihan sampai bisa membuat suatu produk penganan dengan inovasi baru akan memotivasi para ibu rumah tangga untuk berwirausaha mandiri di rumahnya sehingga home industri akan menjamur di Desa Kalirejo. Penganan cokelat yang akan diberikan pelatihannya kepada ibu-ibu di desa tersebut bermacam-macam. Hasil dari kegiatan ini yaitu, cokelat yang isinya buah-buahan seperti kurma dll, cokelat yang berisi crunch ataupun emping jagung, selain itu cokelat yang berisi selai berbagai rasa di dalamnya. Dalam pelatihan ini ibu-ibu rumah tangga di desa akan mendapatkan pelatihan bagaimana cara pengemasan yang baik sehingga menarik untuk dijual pada konsumen selain sasaran penjualan pada toko atau pasar sasaran penjualan juga pada event organizer karena penganan tersebut dapat pula dijadikan souvenir ataupun parsel hantaran.
\end{abstract}

Kata Kunci : Pemberdayaan,Wirausaha Mandiri,Penganan Cokelat

\section{PENDAHULUAN}

\subsection{Analisis Situasi}

Di era globalisasi ini, di tengah-tengah kemajuan teknologi yang sangat cepat sudah seharusnya diimbangi dengan pertumbuhan dan peningkatan kualitas mutu Sumber Daya Manusia yang bukan lagi berangkat dari mindset bukan lagi mencari pekerjaan tetapi bagaimana SDM itu sendiri mampu dan dapat menciptakan lapangan pekerjaan sendiri. Adapun tuntututan dalam menciptakan lapangan pekerjaan diantaranya yang perlu diperhatikan adalah memiliki skill atau keterampilan di bidang usaha tertentu,pandai melihat kebutuhan pasar, dan dapat mengetahui kemampuan ekonomi masyarakat sekitarnya. Saat ini marak nya wirausaha di berbagai daerah menjadi tuntutan utama bagi para SDM di Indonesia.

Pemberdayaan Masyarakat Desa Menurut UU R.I Nomor 6 tahun 2014 Tentang Desa, disebutkan dalam BAB I Pasal 1 nomor 8 yang isinya, Pembangunan desa adalah upaya peningkatan kualitas hidup dan kehidupan untuk sebesarbesarnya kesejahteraan masyarakat Desa. Selanjutnya disebutkan pada nomor 12, Pemberdayaan Masyarakat Desa adalah upaya mengembangkan kemandirian dan kesejahteraan masyarakat dengan meningkatkan pengetahuan, sikap, keterampilan, perilaku, kemampuan, kesadaran, serta memanfaatkan sumberdaya melalui penetapan kebijakan, program, kegiatan, dan pendampingan yang sesuai dengan esensi masalah prioritas kebutuhan masyarakat Desa.

Dan desa pun harus selalu mengumpulkan Data Dasar Keluarga , Potensi Desa Dan Perkembangan Desa Direktorat Jendral Pemberdayaan Masyarakat Masyarakat Dan Desa (Ditjen PMD) Kementrian dalam negeri, Republik Indonesia, telah mengembangkan konsep basis data desa. Berbagai formuir dalam peraturan-peraturan yang terkait tentang desa tersebut diharapkan dikumpulkan oleh masing masing desa setiap tahun. Diharapkan tiap tahun terdapat registrasi sekitar 78 ribu desa se Indonesia, sehingga alangkah baiknya apabila tiap tahunnya semakin banyak peningkatan laporan dari desa-desa di Indonesia khususnya tingkat kesejahteraan masyarakatnya maka diperlukanlah suatu pemberdayaan bagi masyarakat.

Kegiatan pemberdayaan masyarakat yang baik, pada umumnya mensyaratkan adanya proses pendampingan. Ini menjadi penting karen objek pemberdayaan masyarakat adalah masyarakat dengan dinamikanya yang beragam. Fungsi pendampingan adalah untuk memfasilitasi, memotivasi masyarakat serta mengawal agar kegiatan pemberdayaan sesuai dengan maksud dan 
tujuan yang dikehendaki. Pemberdayaan masyarakat community-empowering yang baik seyogyanya mampu mengakomodir berbagai aspek yang berkembang dan dibutuhkan masyarakat. Masyarakat memerlukan peningkatan kesejahteraan, namun juga berharap agar dalam pencapaian kesejahteraan tersebut tidak mengorbankan aspekaspek lain, seperti budaya, keserasian lingkungan dan jati diri sebagai bagian dari sebuah komunitas.

Salah satu Desa di Kota Malang yang dapat peneliti berdayakan melalui pembekalan skill sehingga mampu untuk bersaing dalam hal berwirausaha yaitu Desa Kalirejo, Kecamatan Lawang,Kabupaten Malang. Berikut Data situasi yang ada di Desa kalirejo,Kecamatan Lawang Kabupaten Malang :

1. Keadaan Umum Wilayah Desa/Kelurahan a. Batas wilayah Desa/Kelurahan

\begin{tabular}{|c|l|l|l|}
\hline No & \multicolumn{1}{|c|}{ Letak } & \multicolumn{1}{|c|}{$\begin{array}{c}\text { Desa/ } \\
\text { Kelurahan }\end{array}$} & Kecamatan \\
\hline 1 & $\begin{array}{l}\text { Sebelah } \\
\text { Barat }\end{array}$ & Ketindan & Lawang \\
\hline 2 & $\begin{array}{l}\text { Sebelah } \\
\text { selatan }\end{array}$ & Bedali & Lawang \\
\hline 3 & $\begin{array}{l}\text { Sebelah } \\
\text { Utara }\end{array}$ & Lawang & Lawang \\
\hline 4 & $\begin{array}{l}\text { Sebelah } \\
\text { Timur }\end{array}$ & Sidodadi & Lawang \\
\hline
\end{tabular}

2. Luas Wilayah Desa/kelurahan

\begin{tabular}{|c|c|c|}
\hline No & Penggunaan & Luas ( ha ) \\
\hline \multirow[t]{7}{*}{1} & Permukiman & \\
\hline & $\begin{array}{ll}\text { a. Permukiman Pejabat } \\
\text { Pemerintah }\end{array}$ & \\
\hline & b. Permukiman ABRI & \\
\hline & c. Pemukiman Real Estate & \\
\hline & d. Permukiman KPR-BTN & \\
\hline & e. Permukiman Umum & \\
\hline & Total Luas Permukiman & \\
\hline \multirow[t]{6}{*}{2} & Pertanian Sawah & \\
\hline & a. $\quad$ Sawah inggris & 20 ha \\
\hline & b. Sawah setengah Teknis & 19 ha \\
\hline & c. Sawah tadah hujan & - \\
\hline & d. Sawah pasang surut & - \\
\hline & Total Luas Pertanian sawah & 39 ha \\
\hline \multirow[t]{2}{*}{3} & Ladang / Tegalan & 98 ha \\
\hline & Total Luas Ladang & \\
\hline \multirow[t]{5}{*}{4} & Perkebunan & \\
\hline & a. Rakyat & 21 ha \\
\hline & b. Negara & - \\
\hline & c. Swasta & - \\
\hline & Total Luas Perkebunan & 21 ha \\
\hline \multirow[t]{3}{*}{5} & Padang Rumput/gembala & - \\
\hline & Tanaman Ternak & - \\
\hline & Total Luas Padang Rumput & \\
\hline
\end{tabular}

3. Topografi dan Bentang Lahan

\begin{tabular}{|c|l|l|}
\hline No & \multicolumn{1}{|c|}{ Uraian } & \multicolumn{1}{|c|}{ Luas } \\
\hline 1 & Dataran & 369 ha \\
\hline 2 & Perbukitan/Pegunungan & 30 ha \\
\hline
\end{tabular}

4. Pertumbuhan Penduduk

\begin{tabular}{|l|l|l|}
\hline No & \multicolumn{1}{|c|}{ Keterangan } & Jumlah \\
\hline 1 & Jumlah penduduk tahun ini & $\begin{array}{l}10.859 \\
\text { orang }\end{array}$ \\
\hline 2 & $\begin{array}{l}\text { Jumlah penduduk tahun } \\
\text { lalu }\end{array}$ & $\begin{array}{l}10.899 \\
\text { orang }\end{array}$ \\
\hline
\end{tabular}

5. Jumlah Penduduk Berdasarkan Jenis Kelamin

\begin{tabular}{|c|l|l|}
\hline No & \multicolumn{1}{|c|}{ Status } & Keterangan \\
\hline 1 & Perempuan & 5341 orang \\
\hline 2 & Laki-Laki & 5518 orang \\
\hline 3 & Kepala Keluarga & $3283 \mathrm{KK}$ \\
\hline 4 & Rumah Tangga & $72 \mathrm{RT}$ \\
\hline
\end{tabular}

6. Kualitas Angkatan Kerja

\begin{tabular}{|c|l|c|}
\hline No & \multicolumn{1}{|c|}{ Keterangan } & Uraian \\
\hline 1 & $\begin{array}{l}\text { Jumlah Angkatan kerja } \\
\text { tidak tamat SD/ Sederajat }\end{array}$ & 1400 \\
\hline 2 & $\begin{array}{l}\text { Jumlah Angkatan kerja } \\
\text { tamat SLTP/Sederajat }\end{array}$ & 1895 \\
\hline 3 & $\begin{array}{l}\text { Jumlah Angkatan kerja } \\
\text { tamat SLTA/Sederajat }\end{array}$ & 2800 \\
\hline 4 & $\begin{array}{l}\text { Jumlah Angkatan kerja } \\
\text { tamat SD/Sederajat }\end{array}$ & 3814 \\
\hline 5 & $\begin{array}{l}\text { Jumlah Angkatan kerja } \\
\text { tamat perguruan tinggi }\end{array}$ & 167 \\
\hline 6 & $\begin{array}{l}\text { Jumlah Angkatan kerja } \\
\text { tamat Diploma }\end{array}$ & 252 \\
\hline
\end{tabular}

Dari data-data tersebut diatas berimplikasi terhadap jumlah pengangguran yang besar terutama pada kaum perempuan di Desa Kalirejo yang mayoritas hanya menjadi ibu rumah tangga, selain itu UMKM yang sangat sedikit hanya 21 industri rumah tangga selebihnya menjadi buruh di UMKM tersebut mengingat tingginya jumlah penduduk yang tidak tamat SD/sederajat. Selain itu masyarakat Pra Sejahtera di Desa Kalirejo mencapai $265 \mathrm{KK}$.

Berikut beberapa bangunan pra sejahtera yang banyak ditemukan di desa tersebut. 


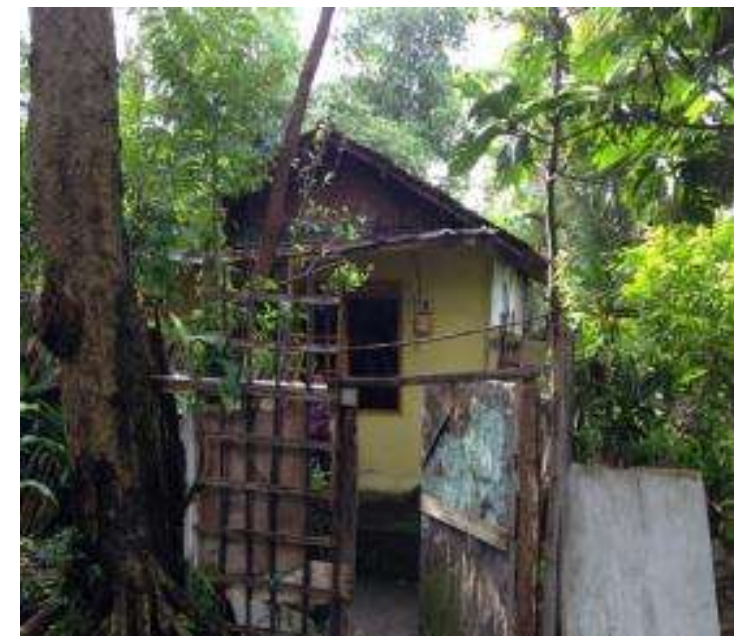

Gb 1 : Rumah masyarakat Pra Sejahtera Desa Kalirejo

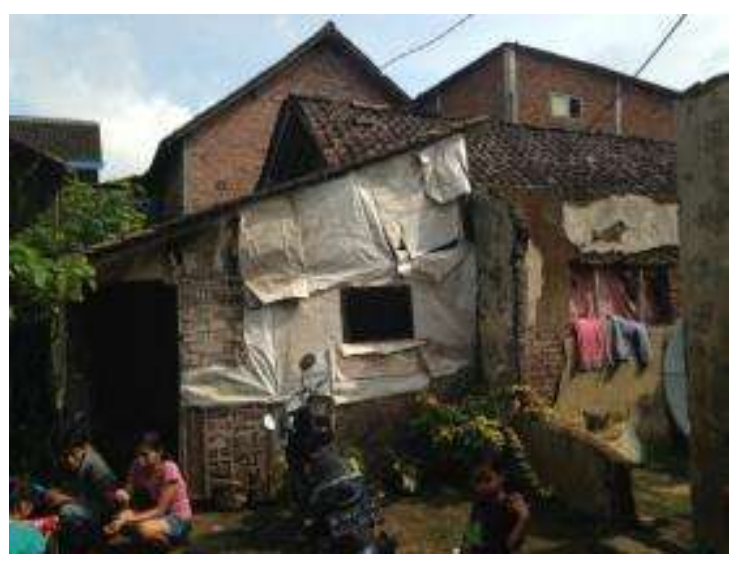

Gambar 2. Rumah masyarakat Pra Sejahtera Desa Kalirejo

Maka dari hal tersebut, kemampuan masyarakat yang dapat dikembangkan tentunya banyak sekali seperti kemampuan untuk berusaha, kemampuan untuk mencari informasi, kemampuan untuk mengelola kegiatan, kemampuan dalam pertanian dan masih banyak lagi sesuai dengan kebutuhan atau permasalahan yang dihadapi oleh masyarakat. Apa yang dikembangkan dari masyarakat, yaitu potensi atau kemampuannya, dan sikap hidupnya. Kemampuan masyarakat meliputi antara lain kemampuan untuk bertani, berternak, melakukan wirausaha, atau keterampilan membuat home industri; dan masih banyak lagi kemampuan dan keterampilan masyarakat yang dapat dikembangkan.

Dalam rangka mengembangkan kemampuan dan keterampilan masyarakat, dapat dilakukan dengan berbagai cara. Contoh dengan mengadakan pelatihan atau mengikutkan masyarakat pada pelatihan-pelatihan pengembangan kemampuan dan keterampilan yang dibutuhkan. Dapat juga dengan mengajak masyarakat mengunjungi kegiatan di tempat lain dengan maksud supaya masyarakat dapat melihat sekaligus belajar, kegiatan ini sering disebut dengan istilah studi banding.

\subsection{Permasalahan Mitra}

Berdasarkan analisis situasi di atas, maka beberapa temuan yang telah diidentifikasi sebagai permasalahan mitra antara lain adalah :

- Rendahnya angkatan kerja yang tidak tamat $\mathrm{SD} /$ Sederajat

- Sebagian besar kaum wanita/perempuan disana hanya sebagai Ibu rumah Tangga

- Masih tingginya masyarakat Pra Sejahtera mencapai $256 \mathrm{KK}$

- Rendahnya industri kecil rumahan

- Rendahnya kemauan para Ibu rumah tangga untuk memulai berwirausaha

\subsection{Solusi}

Program Pengabdian kepada Masyarakat atau Iptek Bagi Masyarakat yang disusun ini dimaksudkan untuk mewujudkan pemberdayaan terhadap ibu-ibu rumah tangga yang ada di Desa Kalirejo untuk memiliki mindset berwirausaha sehingga mampu menghasilkan profit dan benefit bagi keluarganya serta meminimalisir tingginya masyarakat pra sejahtera di sana, melalui metode pelatihan pembuatan suatu produk yang memiliki nilai ekonomis tinggi dengan berinovasi terhadap pembuatan penganan cokelat dengan berbagai varian isi,rasa,dan pengemasan sehingga memiliki nilai jual yang tinggi apabila dipasarkan di masyarakat.

Program ini concern kepada ibu rumah tangga dengan latar belakan keluarga Pra Sejahtera dengan memberi pelatihan sampai bisa membuat suatu produk penganan dengan inovasi baru akan memotivasi para ibu rumah tangga untuk berwirausaha di rumahnya sehingga home industri akan menjamur di Desa Kalirejo. Penganan cokelat yang akan diberikan pelatihannya kepada ibu-ibu di desa tersebut bermacam-macam sebagai contoh yaitu cokelat yang isinya buah-buahan seperti kurma dll, cokelat yang berisi crunch ataupun emping jagung, selain itu cokelat yang berisi selai berbagai rasa di dalamnya. Dalam pelatihan ini ibu-ibu rumah tangga di desa akan mendapatkan pelatihan bagaimana cara pengemasan yang baik sehingga menarik untuk dijual pada konsumen selain sasaran penjualan pada toko atau pasar sasaran penjualan 
juga pada event organizer karena penganan tersebut dapat pula dijadikan souvenir ataupun parsel hantaran.

Berikut contoh inovasi cokelat yang mampu meningkatkan nilai jual apabila ibu-ibu rumah tangga di desa tersebut berwirausaha mandiri setelah mendapat pelatihan:

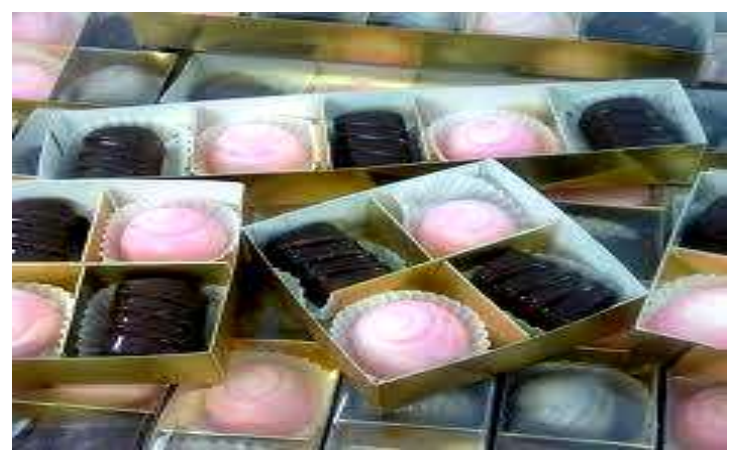

Gb 3. Varian cokelat untuk souvenir

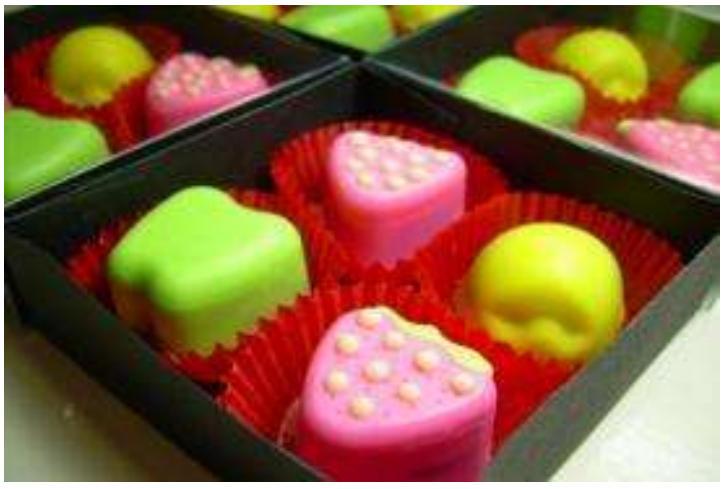

Gb 4. Varian cokelat buah

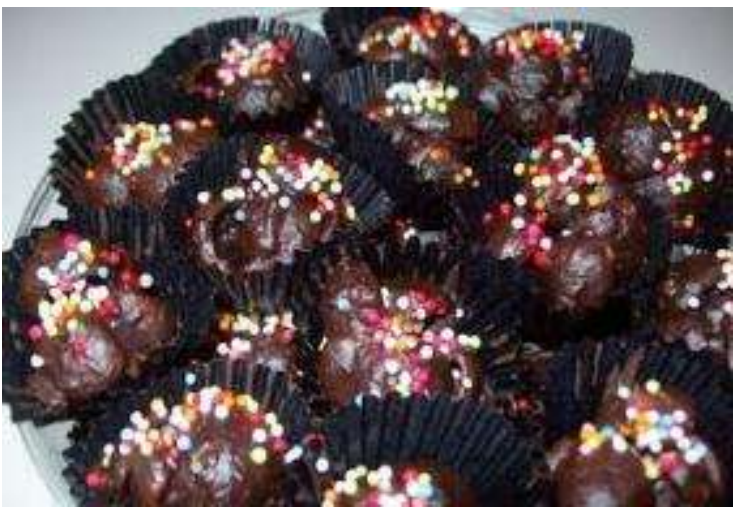

Gambar 5. Varian cokelat crunch

\subsection{Target Luaran}

- Jasa berupa dibukanya home industri yang bergerak di bidang penganan cokelat

- Produk berupa inovasi varian cokelat yang memiliki nilai ekonomi yang tinggi

\subsection{Rencana Target Capaian}

\begin{tabular}{||c||l||l||}
\hline No & \multicolumn{1}{|c|}{ Jenis Luaran } & $\begin{array}{l}\text { Indikator } \\
\text { Capaian }\end{array}$ \\
\hline \hline 1. & $\begin{array}{l}\text { Publikasi ilmiah di jurnal } \\
\text { nasional (ber ISSN) }\end{array}$ & Draf \\
\hline \hline 2. & $\begin{array}{l}\text { Pemakalah } \\
\text { dalam temu } \\
\text { ilmiah }\end{array}$ & Nasional \\
\cline { 2 - 3 } Lokal & Tidak ada \\
\hline \hline 3. & Bahan ajar & Tidak ada \\
\hline \hline 4. & $\begin{array}{l}\text { Luaran lainnya jika ada } \\
\text { (Teknologi Tepat Guna, } \\
\text { Model/Purwarupa/Desain/ } \\
\text { Karya seni/ Rekayasa } \\
\text { Sosial) }\end{array}$ & Tidak ada \\
\hline \hline 5. & $\begin{array}{l}\text { Tingkat Kesiapan } \\
\text { Teknologi (TKT) }\end{array}$ & Skala 1 \\
\hline
\end{tabular}

\section{METODE KEGIATAN}

1. Minggu ke I, Persiapan survey lokasi mitra yang sebagian besar penduduknya hanya menjadi ibu rumah tangga dan tidak memiliki usaha atau home industri secara mandiri di rumah, Meminta izin kerjasama kepada perangkat desa yang berkaitan langsung terhadap warganya terkait akan dilaksanakannya program pelatihan terhadap ibu-ibu rumah tangga di daerah tersebut.

2. Minggu ke I, Menjalin kerjasama dengan cara menghubungi Mitra yang akan memberikan pelatihan cara-cara pembuatan penganan cokelat dengan berbagai varian isi,rasa,dan pengemasan.

3. Minggu ke II melakukan sosialisasi awal kepada sasaran yang akan diberdayakan untuk dilakukan pelatihan pembuatan penganan cokelat dengan berbagai varian isi,rasa,dan pengemasan

4. Minggu ke III, Pelaksanaan pelatihan pembuatan penganan cokelat dengan berbagai varian isi,rasa,dan pengemasan. Serta pembagian bahan-bahan resep kepada sasaran yang diberikan pelatihan beserta resep dan cara pengemasan yang baik dan menarik sehingga memiliki nilai jual yang tinggi.

5. Minggu ke IV, Pelaporan hasil IbM dan pelaporan anggaran pengeluaran program IbM.

\section{HASIL DAN PEMBAHASAN}

5.1. Pelaksannaan Kegiatan Pelatihan Pembuatan Penganan Cokelat Dengan Varian Inovasi Isi,Rasa 
dan Pengemasan Kepada Ibu Rumah Tangga di Desa Kalirejo Kecamatan Lawang Kabupaten Malang

Kegiatan pelatihan dilakukan kepada Ibu rumah tangga di Desa Kalirejo dengan beberapa kegiatan dan langkah sebagai berikut :

1. Pengabdi mendatangkan narasumber untuk melakukan pelatihan kepada Ibu rumah tangga yang berlatar belakang masyarakat Pra Sejahtera di desa Kalirejo,kabupaten Malang

2. Pengabdi mempersiapkan bahan-bahan yang digunakan selama pelatihan berlangsung diantaranya bahan yang diperlukan yaitu : Cokelat blok (Dark Chocolatte), Cokelat warnawarni dengan varian rasa, Susu Milk,Emulfisier Cokelat,Sprinkle, Kurma, Selai,Crunch,Emping Jagung,Panci,Kompor dll.

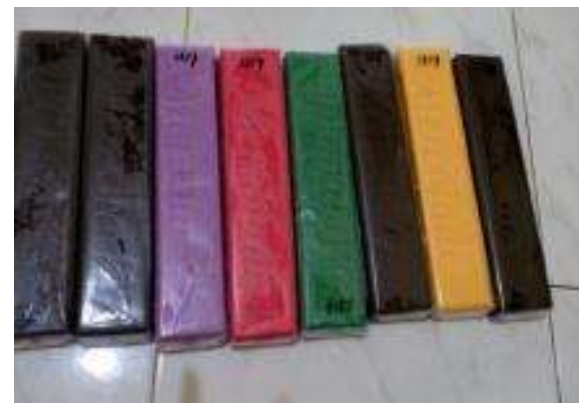

Gb 6. Bahan baku pembuatan penganan Cokelat

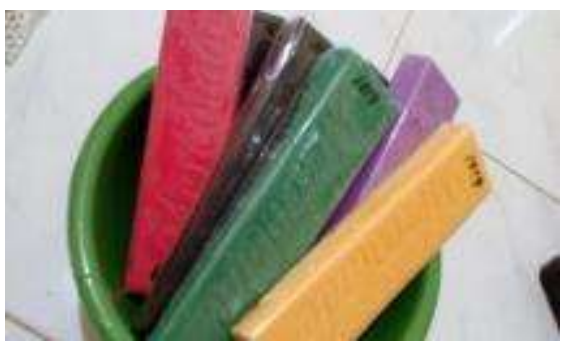

Gb 7. Bahan baku pembuatan penganan Cokelat

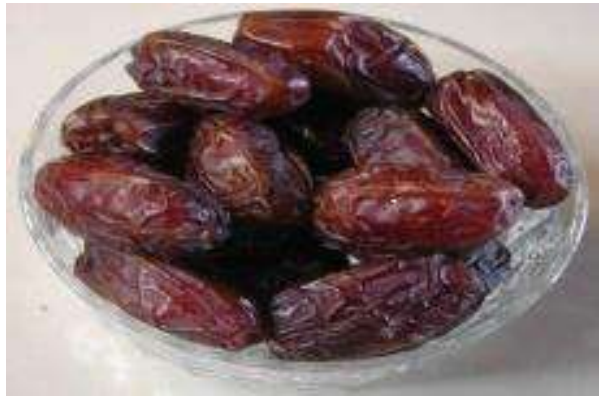

Gb 8. Isian dari Cokelat
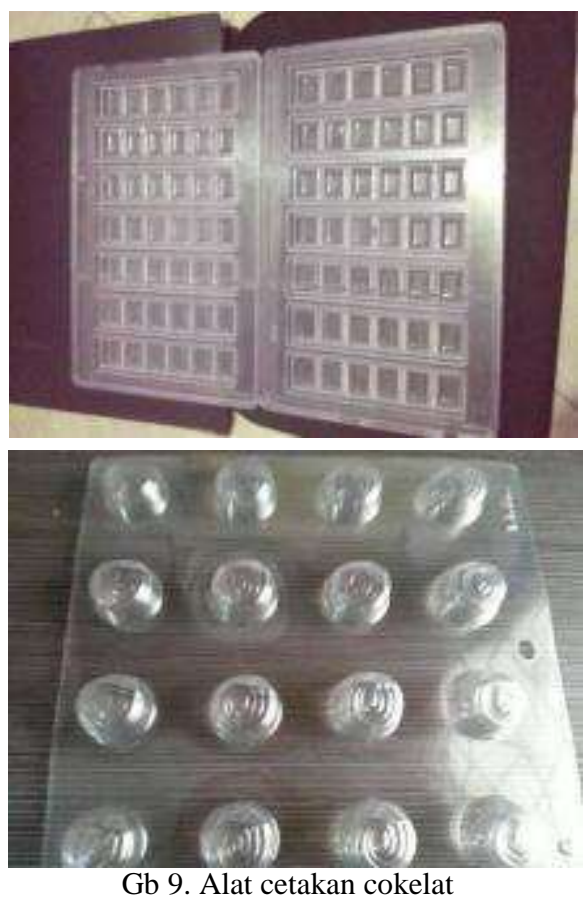

3. Selanjutnya Tahapan-tahapan pembuatan cokelat dibagikan oleh pengabdi kepada Ibu rumah tangga berlatar belakang masyarakat pra sejahtera di Desa Kalirejo berbentuk Resep yang dibagikan kepada Mitra, berikut resep dari penganan cokelat dengan variasi dan inovasi isi:

\section{RESEP COKELAT ISI KURMA}

Bahan:

- Kurma secukupnya buang bijinya

- Kacang mete goreng

- 1 Cokelat Batang

- Mentega/Margarin

- Springkel warna-warni

Cara Pembuatan :

- Buang biji kurma ganti dengan kacang mete yang sudah di potong

- Lelehkan cokelat dengan cara di tim, beri sedikit margarin,Setelah meleleh angkat

- Celupkan kurma isi mete ke dalam cokelat,tiriskan,taburi dengan hiasan springkel

- Dinginkan dalam kulkas, masukan dalam toples

RESEP COKELAT ISI SELAI

Bahan :

- Cokelat Batang secukupnya

- Selai Strawberry, Blueberry, Nanas dll secukupnya

Alat :

- Cetakan Cokelat

- Panci Kecil untuk tim cokelat 
Cara Pembuatan :

- Siapkan cetakan cokelat yang bersih dan kering

- Potong-potong cokelat ukuran kecil,letakkan di dalam panci kecil

- Tim dengan api kecil sampai meleleh aduk-aduk dengan sendok

- Masukkan ke dalam cetakan cokelat hingga setengah bagian saja

- Masukkan ke dalam lemari pendingin/freezer kurang lebih 5 menit

- Keluarkan dari lemari pendingin (jika sudah beku)

- Isi bagian tengah cokelat dengan selai sesuai selera

- Isi kembali dengan cokelat sampai penuh pada bagian cetakan

- Masukkan kembali dalam freezer selama kurang lebih 5 menit

- Cokelat siap dihidangkan

\section{RESEP COKELAT COCO CRUNCH}

Bahan :

- 1 blok Cokelat batang

- Secukupnya Choco Crunch

- Sprinkle

Cara Pembuatan :

- Potong-potong coklat batangan lalu lelehkan

- Aduk cokelat yg sudah di lelehkan lalu masukkan choco crunch bertahap

- Taruh dalam wadah kertas beberapa gumpalan choco crunch yg telah di campur lelehan coklat Taburkan butiran sprinkle dan masukkan kedalam kulkas supaya cokelat mengeras dan lebih menyatu dengan choco crunch. Dan cemilan siap dihidangkan

Berikut hasil dari pelatihan pembuatan penganan cokelat Kegiatan Pelatihan Pembuatan Penganan Cokelat Dengan Varian Inovasi Isi,Rasa dan Pengemasan Kepada Ibu Rumah Tangga di Desa Kalirejo Kecamatan Lawang Kabupaten Malang :

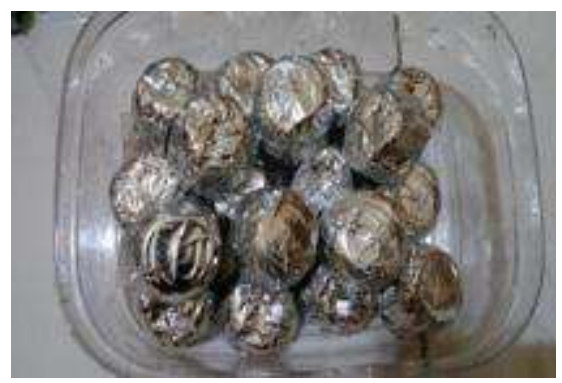

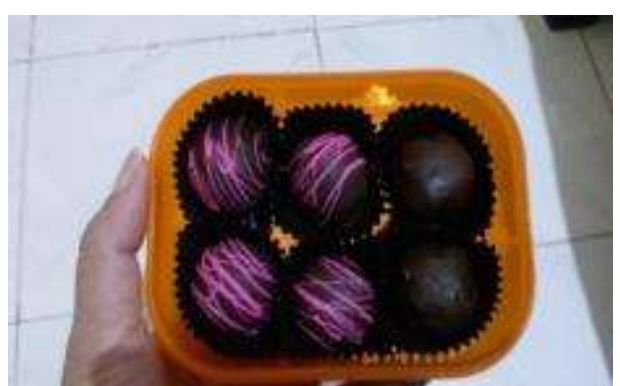
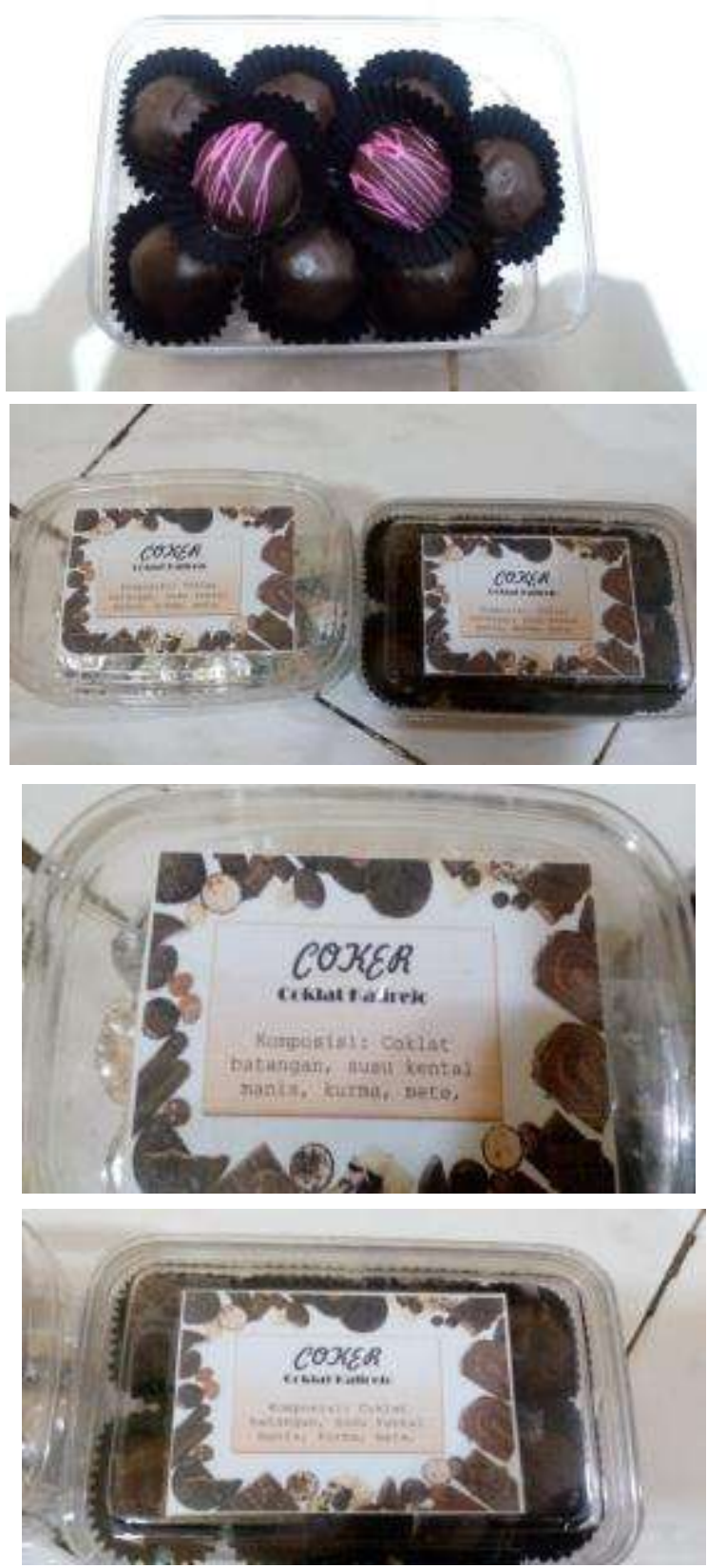

Gb 10. Hasil Pelatihan dan Labeling Pengemasan

4. Guna terjadi proses jangka panjang dalam pembuatan penganan cokelat yang bervariasi dan berinovasi maka pengabdi membagikan sumbangan berupa parcel bahan-bahan pokok 
utama dalam pembuatan penganan cokelat ini sehingga dapat diberdayakan oleh Ibu-ibu masyarakat pra sejahtera di Desa Kalirejo Kabupaten Malang.

\section{KESIMPULAN DAN SARAN}

\section{Kesimpulan}

Berdasarkan hasil kegiatan yang sudah dilakukan di lokasi kegiaatn maka dapat disimpulkan beberapa hal sebagai berikut :

1. Selama ini para Ibu rumah tangga yang berlatar belakang masyarakat pra sejahtera hanya mengandalkan biaya dari kepala keluarga tanpa memiliki kemauan untuk berwirausaha dengan alasan tidak memiliki dana yang lebih untuk membuka usaha.

2. Belum adanya pelatihan-pelatihan untuk mendobrak kewirausahaan mandiri kepada ibuibu rumah tangga di sana, program hanyalah dari PKK dan pengajian saja namun tidak mencakup upaya pelatihan kewirausahaan mandiri.

3. Antusias ibu-ibu rumah tangga yang berlatar belakang masyarakat pra sejahtera terhadap pelatihan, dan bingkisan sumbangan yang telah diberikan untuk dimanfaatkan kedepannya.

\section{Saran :}

1. Diperlukan koordinasi yang baik antara pengurus PKK,RW dan RT setempat terhadap warganya khususnya Ibu rumah tangga berlatar belakang masyarakat Pra Sejahtera untuk mendongkrak peran serta mereka berwirausaha mandiri sehingga tingkat kesejahteraan masing-masing keluarga di Desa Kalirejo dapat meningkat secara bertahap.

2. Diperlukan pendampingan pelatihan secara berkelanjutan guna monitoring dan evaluasi terhadap program IbM yang sudah dilaksanakan, sehingga tidak hanya menjadi pelatihan satu kali saja namun berkesinambungan.

\section{DAFTAR PUSTAKA}

1. Badan Pemberdayaan Masyarakat Kabupaten Malang, 2007, Buku Panduan Profil Desa dan Kelurahan Kabupaten Malang, Malang,hal 1

2. ZainulArifin,http://www.visioner.id/opini/9933/p rogram-pemberdayaan-masyarakat-upayameningkatkan- kesejahteraan-masyarakat-desa2.html, diakses tanggal 20 Juli 2016

3. Badan Pemberdayaan Masyarakat Kabupaten Malang, 2007, Daftar Isian Data Dasar Profil Desa/keluraha Kalirejo, Kecamatan Lawang, Malang

4. Kelurahan Kalirejo Lawang, 2016,Data UMKM, Malang

5. Nur Yasin, http://bapemas.jatimprov.go.id/ index.php/home-mainmenu-1/90-berita/492-

opini- pemberdayaan-masyarakat-dalampembangunan-desa, diakses tanggal 20 juli 2016 